\title{
Description of a novel variant in the MAMLD1 gene in isolated hypospadias
}

\section{Descripción de una nueva variante del gen MAMLD1 en hipospadias aislado}

\author{
Nicolás Fernández ${ }^{1,2}$ Jattin Pabon ${ }^{3}$ Paola Ayala $^{3}$ Jaime Pérez ${ }^{1,2}$ Ana María Ortiz ${ }^{1,2}$ Ignacio Zarante ${ }^{3}$ \\ ${ }^{1}$ Unidad de Urología, Hospital Universitario San Ignacio, Colombia \\ 2 Pontificia Universidad Javeriana, Colombia \\ 3 Instituto de Genética Humana, Facultad de Medicina, Pontificia \\ Universidad Javeriana, Colombia \\ Address for correspondence Nicolás Fernández, \\ Unidad de Urología, Hospital Universitario San Ignacio, Colombia \\ (e-mail: Fernandez.j@javeriana.edu.co; \\ nicolasfernandezb@gmail.com).
}

Urol Colomb 2018;27:105-109.

\begin{abstract}
Keywords

- genitourinary anomalies

- hypospadias

- MAMLD1

- genetic variant
\end{abstract}

\section{Resumen}

Introduction Hypospadias is a multifactorial malformation. Among previously described genes, the MAMLD1 has recently been identified in association with the development of hypospadias. So far, there are no studies in Latin America addressing this gene. The aim of this paper is to describe the presence of variants in exon 3 of the MAMLD1 in our population.

Materials and Methods Using the Bio-Repository's database of the Human Genetics Institute, we identified 51 patients between 2008 and 2012 with varying degrees of isolated hypospadias. Exon 3 was sequenced looking for polymorphisms. These were assessed with in silico prediction algorithms to describe the effect of these changes on the function and structure of the protein.

Results Four patients with 3 variants were identified. The p.S364P variant has not been previously described and has a deleterious effect. The other two, rs41313406 and rs61740566, have been previously described and are not considered variations with harmful effect on the protein function. The genotype-phenotype correlation varies in severity between the variables described.

Conclusions For the first time a Latin American population is molecularly analyzed. The p. S364P variation has never been described before. Variations with different degrees of hypospadias are described.

Introducción El hipospadias es una malformación multifactorial. Dentro de los genes asociados descritos, el MAMLD1 se ha identificado recientemente como asociado al desarrollo de esta enfermedad. Hasta el momento no hay estudios en Latinoamérica sobre este gen. El objetivo del presente trabajo es describir la presencia de variantes en el exón 3 del MAMLD1 en nuestra población.

Material and Métodos Basados en los registros del Biorrepositorio del Instituto de Genética Humana, se identificaron 51 pacientes entre el año 2008 y el 2012 con diferentes received

February 26, 2016 accepted September 12, 2016 published online January 10, 2018
DOI https://doi.org/ 10.1016/j.uroco.2016.09.001 ISSN 0120-789X. eISSN 2027-0119.
Copyright ( $\odot$ 2018, Sociedad Colombiana License terms de Urología. Publicado por Thieme Revinter Publicações Ltda., Rio de Janeiro, Brazil. Todos los derechos reservados.

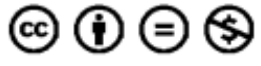


Palabras-Clave

- anomalías genitourinarias

- hipospadias

- MAMLD1

- variante grados de hipospadias aislado. A estos se les realizó la secuenciación del exón 3. Los polimorfismos identificados fueron evaluados con algoritmos de predicción in silico para evaluar el efecto de estos cambios sobre la función y estructura de la proteína.

Resultados Se encontraron 4 pacientes con 3 variantes. La variante p.S364P no ha sido descrita previamente y tiene un efecto deletéreo. Las otras 2, rs41313406 y rs61740566, han sido descritas previamente y no se consideran variaciones con potencial de efecto deletéreo sobre la función de la proteína. La correlación fenotipo-genotipo varía en severidad entre las variables descritas.

Conclusiones Por primera vez se analiza molecularmente una población latinoamericana, encontrando la variante p.S364P no descrita previamente, y 2 variantes ya descritas previamente.

\section{Introduction}

Hypospadias are considered a multifactorial disease given the interaction between molecular events and the environment. Molecular mechanisms are complex. To date, there are around 26 genes associated with the development of hypospadias. Recently, the MAMLD1 gene (Mastermind like domain containing protein 1") association with hypospadias was identified. ${ }^{1}$ Originally known as CXorf6 (Chromosome X open reading frame 6) or F18, the MAMLD1 is a gene first described by Laporte et al. in 1997 in patients with ambiguous genitalia during the study of the X-linked myotubular miotrofia., ${ }^{2,3} \mathrm{~A}$ decreased expression of the MAMLD1 generates a reduction in testosterone levels in early periods of organogenesis around the $8-12$ weeks of gestation. A decrease of $25-30 \%$ in the gene expression reduces levels of testosterone to a $50-60 \%$ of normal values, but never becomes undetectable. ${ }^{5}$ This explains the association with the development of the hypospadias. It has been described the expression of the gene in other tissues like skeletal muscle, brain, placenta and heart. ${ }^{1}$ Interaction of MAMLD1 and co-activation with other genes (STAR CYP11a1, CYP17a1, HSD3b1, INSL1, SF1, HES3, STAT3), in knock-out mice with a normal development of genitals, has shown a more complex molecular function of this gene. ${ }^{2}$ Genotype-phenotype correlation is not always the same because patients with the same mutations present different degrees of clinical severity. ${ }^{4}$ On the other hand, patients with mutations in this gene have normal levels of testosterone after birth and hCG stimulation test is not altered due to the deletion of the MAMLD1. ${ }^{6}$

Given the complexity of the functions and interactions of MAMLD1 and processes yet to characterize as mentioned above, it is necessary to continue further studies on this gene. The purpose of this work is to make a description of variants in exon 3 of the gene MAMLD1 in Colombian patients affected with hypospadias.

\section{Material and Methods}

\section{Population characteristics}

During the period from January 2008 to October 2012, patients with isolated hypospadias were recruited. All types of clinical severity were included using Duckett's classification. Patients were selected from the DNA Bank of urological congenital malformations of the Institute of Human Genetics at the Pontificia Universidad Javeriana. Excluded cases were all syndromic hypospadias registered in the DNA Bank. All recruited cases were captured when surgery was scheduled to correct the congenital defect. All cases had a signed consent by the parents or legal representatives before being included in the study. Once patients were admitted to the study, a questionnaire was filled. The pool of demographic information included data from the patient and his parents, description of the malformation and diagnostic methods, prenatal history and detailed technical information about the surgical procedure. At the time of venipuncture during anesthetic induction, the blood sample was taken from a peripheral vein $(3-5 \mathrm{~mL})$ in tubes with anticoagulants. Subsequent extraction of DNA was made. Storage of samples was at $-20^{\circ} \mathrm{C}$. DNA extraction was performed using the method of salting-out with the Promega Wizard $^{\circledR}$ kit. Extracted DNA was evaluated with spectrophotometry to determine the concentration and absorbance between 260 and 280 nanometers (GeneQuant Amersham Biosienciens ${ }^{\circledR}$ ).

\section{Sample and data processing}

Once DNA was extracted, PCR for exon 3 of the MAMLD1 gene was done. This exon was divided into three fragments through the design of primers with the program Primer $3^{\circledR}$. Amplification according to standardized protocols in the laboratory of Molecular Biology and Genetics at the Institute of Human Genetics at the Pontificia Universidad Javeriana was made using a thermal cycler from BIO-RAD ${ }^{\circledR}$ iCycler. Agarose gels were used stained with $1 \%$ ethidium bromide and visualized using UV light to reveal the size of the fragments.

Subsequently purification was performed using PureLink $^{\circledR}$ PCR Purification kit and Affimetrix ${ }^{\circledR}$ ExoSAP-IT for PCR product cleanup. Purified samples were then verified using electrophoresis in agarose $1 \%$. Sequencing by Sanger method was performed with the ABI PRISM ${ }^{\circledR} 3730 X L$ Analyzer (96 capillary type). Finally, analysis of the sequences was performed using Squencer ${ }^{\circledR} 5.0$ software. Prediction analysis in-silico was conducted using Polyphen ${ }^{\circledR}$, SIFT $^{\circledR}$, SNP\&GO ${ }^{\circledR}$, Mutation-taster ${ }^{\circledR}$ and Mustab ${ }^{\circledR}$.

Results were analyzed according to the classification of the degree of the hypospadias. A population analysis was 
performed calculating the allele frequencies by direct counting method and Harlequin ${ }^{\circledR} 3.1$ to assess the Hardy Weinberg equilibrium.

\section{Results}

During the study period 67 cases were collected. This corresponds to $34 \%$ of the total number of individuals included in the Bank. Of these, 51 samples for analysis were processed. Average age at the time of surgery was 5 years ( \pm 4 years). The $50.9 \%$ of the cases came from Cundinamarca and the remaining from different departments of the country. According to the classification of Duckett, the most frequently operated degree was scrotal (35.29\%), followed by penile hypospadias (25.49\%).

Sequencing analysis identified 3 changes in exon 3 of the MAMLD1 gene in 4 out of 51 analyzed individuals (-Table 1 and - Fig. 1). Two changes were identified in patient number 21. The first identified change was p.S364P. This variant has not been previously described. There is only information of two cases of this variant in the latino population in the Exome Aggregation Consortium database. A frequency of 0.0002148 in latinos and a MAF $=2.291 \mathrm{e}-05$ has been described. To assess the potential impacts of this variant in the protein, a damaging impact in 3 out of 5 algorithms was identified (-Table $\mathbf{1}$ ). The second change is the same as the one identified in patient number 130. In patient number 14 the variant p.P334S (rs41313406) was identified. According to prediction bioinformatic algorithms, this change has a potential impact on the function of the protein (-Table 1). This same variant was identified in patient number 64 . The third change, p.V432A (rs61740566), present in patients number 21 and number 130 , was identified as benign in 5 of the 6 algorithms. This change has been previously described (-Table 1 ). Allele frequency analysis showed that the population is in balance for each variant according to Hardy-Weinberg model $(p=1.000)$. The SNP rs41313406 presented genotype frequencies for our study of CC (0.960), CT (0.039) and TT (0). There are two populations reported in the literature reporting genotype frequencies similar to those found in the present study: the U.S. population and the African American and Caucasian mix. People with African American and Caucasian mix present the following frequencies: CC (0.842), CT (0.158) in 38 analyzed individuals. This variant was found in the Latin American population. The SNP rs61740566 presented genotype frequencies in our study of TT (0.960), TC (0.039) and CC (0). There are also two populations reported in the literature with frequencies similar to ours. The North American population presents the following sequences: TT (0.884), CT (0.092) and CC (0.024), in 2272 individuals analyzed.

\section{Discussion}

This is the first study in our population and in Latin America that analyzes the presence of variations in the MAMLD1 gene. Three nucleotide changes were found in four of the 51 analyzed patients (-Table 1). The p.S364P change has not been reported previously. As with other variants of the MAMLD1 associated with hypospadias, the correlation of the genotype-phenotype changes from patient to patient. ${ }^{7,8}$ Analysis in silico of this change showed a deleterious effect on

Tabla 1 Demographic description of patients with detected variants and their impact on the MAMLD1 protein

\begin{tabular}{|c|c|c|c|c|c|c|c|}
\hline Patient & Age & Meatus & rs\# & $\begin{array}{l}\text { Variant in } \\
\text { proteine }\end{array}$ & \multicolumn{3}{|l|}{ Genetic variant } \\
\hline PTE 14 & 39 & Scrotal & rs41313406 & P334S & \multicolumn{3}{|c|}{$\begin{array}{l}\text { c. } 1000 \mathrm{C}>\mathrm{T} \\
\text { CDNA.1175C }>\text { T g. } 109232 \mathrm{C}>\mathrm{T}\end{array}$} \\
\hline PTE 21 & 10 & Glanular & ND & S364P & \multicolumn{3}{|c|}{$\begin{array}{l}\text { c. } 1090 \mathrm{~T}>\mathrm{C} \\
\text { c. } 1265 \mathrm{~T}>\mathrm{C} \text { g. } 109322 \mathrm{~T}>\mathrm{C}\end{array}$} \\
\hline PTE 21 & 10 & Glanular & rs61740566 & V432A & \multicolumn{3}{|c|}{$\begin{array}{l}\text { c. } 1439 \mathrm{~T}>\mathrm{C} \\
\text { cDNA.1614T }>\text { C g. } 109671 \mathrm{~T}>\mathrm{C}\end{array}$} \\
\hline PTE 130 & 6 & Glanular & rs61740566 & V432A & \multicolumn{3}{|c|}{$\begin{array}{l}\text { c.1439T >C } \\
\text { cDNA.1614T > g.109671T >C }\end{array}$} \\
\hline PTE 64 & 8 & Penile & rs41313406 & P334S & \multicolumn{3}{|c|}{$\begin{array}{l}\text { c. } 1000 \mathrm{C}>\mathrm{T} \\
\text { CDNA. } 1175 \mathrm{C}>\mathrm{Tg} .109232 \mathrm{C}>\mathrm{T}\end{array}$} \\
\hline \multirow[t]{2}{*}{ Patient } & \multicolumn{7}{|c|}{ In silico algorithms } \\
\hline & Polyphen & SIFT & Provean & SNP\&GO & Mutation taster & Mustab & Described \\
\hline PTE 14 & $\begin{array}{l}\text { Probably } \\
\text { damaging }\end{array}$ & Damaging & Neutral & Neutral & Polymorphism & $\begin{array}{l}\text { Diminishes } \\
\text { stability }\end{array}$ & $\begin{array}{l}\text { Yes } 1000 \text { genomas Medellín } \\
C=94 \% \mathrm{~T}=6 \% \mathrm{MAF}=4 \%\end{array}$ \\
\hline PTE 21 & ND & Damaging & Deleterious & Neutral & Polymorphism & $\begin{array}{l}\text { Diminishes } \\
\text { stability }\end{array}$ & $\begin{array}{l}\text { No } 1000 \mathrm{G} \text { ExAC } 0.0002148 \text { en latinos } \\
\mathrm{MAF}=2.291 \mathrm{e}-05 \mathrm{No} \mathrm{NCBI}\end{array}$ \\
\hline PTE 21 & Benigne & Tolerable & Neutral & Neutral & Polymorphism & $\begin{array}{l}\text { Diminishes } \\
\text { stability }\end{array}$ & $\begin{array}{l}\text { 1000G Medellin } \\
\mathrm{T}=99 \% \mathrm{C}=1 \% \mathrm{MAF}=0.05 \mathrm{ExAC} \\
\text { Latinos }=0.007632 \text { Total }=0.01835\end{array}$ \\
\hline \multirow[t]{2}{*}{ PTE 130} & Benigne & Tolerable & Neutral & Neutral & Polymorphism & $\begin{array}{l}\text { Diminishes } \\
\text { stability }\end{array}$ & $\begin{array}{l}\text { 1000G Medellin } \\
\mathrm{T}=99 \% \mathrm{C}=1 \% \mathrm{MAF}=0.05 \mathrm{ExAC} \\
\text { Latinos }=0.007632 \text { Total }=0.01835\end{array}$ \\
\hline & $\begin{array}{l}\text { Probably } \\
\text { damaging }\end{array}$ & Damaging & Neutral & Neutral & Polymorphism & $\begin{array}{l}\text { Diminished } \\
\text { stability }\end{array}$ & $\begin{array}{l}1000 \text { genomas Medellin } \\
\mathrm{C}=94 \% \mathrm{~T}=6 \% \mathrm{MAF}=4 \%\end{array}$ \\
\hline
\end{tabular}



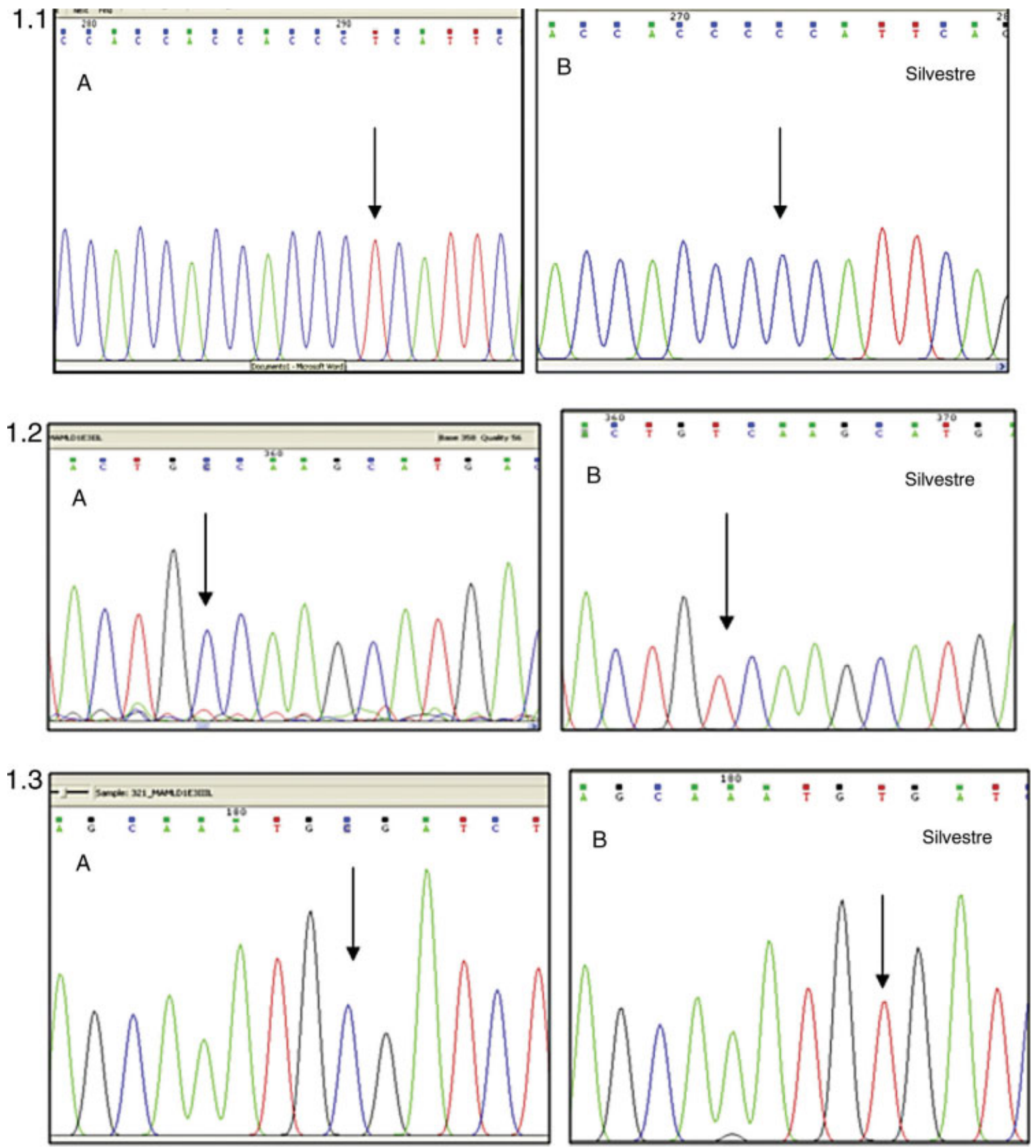

Fig. 1 Electroferograms of the three identified variants. The arrows show the variants in each electroferogram. (1.1) (A) Patients number 14 and number 64 with the p.P334S variant (rs41313406). (B) Wild-type sequence. (1.2) (A) Patient number 21 with the p.S364P variant. (B) Wild-type sequence. (1.3) (A) Patients number 21 and number 130 with the p.V432A variant (rs61740566). (B) Wild-type sequence.

the protein. In addition, the amino-acid change that occurs with this variant changes the polarity of the protein and must therefore have a greater impact on the normal functioning of the protein.

Two of the SNPs identified, rs41313406 and rs61740566, have already have been reported in other studies. The SNP rs41313406 was found in two of the 51 patients with isolated hypospadias, and when analyzing the change in the protein, it is observed that it is likely to damage, contrary to some previous reports. $^{2}$ Chen et al, described eleven patients with the SNP,
Fukami in 2008 and Kalfa in 2012 reported 14 patients. They state that the amino-acid change generates no effect on the protein. They argue this because the variant is not located on a highly conserved region and for that reason, it might not be deleterious. With respect Kalfa's findings, their results differ from other authors and ours because the change in the protein reported does not match the position we identified (p.P359S vs. p.P334S), but yet, it has the same SNP number. ${ }^{3,5}$ Kalfa's work, this change is defined as a mutation. Other authors report this effect as a polymorphism. Our in silico analysis suggests a 
negative effect on the protein. Interestingly, cases reported by other authors, and ours have the same phenotype of proximal hypospadias.

On the other hand, the SNP rs61740566 found in two of the 51 patients with isolated hypospadias, has no effect on the protein. Our results are consistent with other authors who have found it even in healthy controls. ${ }^{9,10}$ The phenotype of our two individuals with the variant is distal hypospadias, compared with those reported by Kalfa et al. that had proximal hypospadias. $^{11,12}$

Our results as well as other authors, demonstrate that the phenotype varies in different degrees of severity of the hypospadias, with the variations of the MAMLD1.

We acknowledge that the majority of cases are proximal due to do the fact that our hospital is a reference center. We believe the average age of surgery is influenced by the administrative difficulties in our health system, that makes it harder for patients to consult a specialist. Nonetheless this limitations, they do not affect the results of our study.

\section{Conclusions}

For the first time in our country and our region, we assess on a molecular level patients with isolated hypospadias, looking for changes in the MAMLD1 gene. This new mutation gives more information about this recently described gene and the development of hypospadias. The variability of the phenotype in patients with the same genotype predicts a complex pathophysiology of the MAMLD1 gene. Future studies must focus on the co-expression with other genes and possible epigenetic and environmental factors associated with genetic variants in patients with hypospadias.

\section{Ethical Responsibilities}

\section{Protection of people and animals}

The authors state that the procedures conformed to the ethical standards of human experimentation committee responsible and according to the World Medical Association and the Declaration of Helsinki.

\section{Confidentiality of data}

The authors declare that they have followed the protocols of the workplace on the publication of patient data.

\section{Right to privacy and informed consent}

The authors have obtained the informed consent of patients and/or subjects referred to in Article consent. This document is held by the corresponding author.
Conflict of interest

The authors declare that they have no conflicts of interests.

\section{Acknowledgements}

Mercedes Cano, nurse of the Functional Urology Unit at the Hospital Universitario 12 de Octubre, for her assistance in the protocol and the urodynamic studies.

\section{References}

1 Fernández FN, Pérez FJ, Zarante FI. ¿Son las hipospadias la expresión de diferentes enfermedades? MAMLD1: un nuevo gen candidato para hypospadias. Urol Colomb [online] 2015;24:155-160, DOI 10.1016/j.uroco.2015.06.005

2 Miyado FM, Nakamura FM, Miyado FK, et al. Mamld1 deficiency significantly reduces mRNA expression levels of multiple genes expressed in mouse fetal Leydig cells but permits normal genital and reproductive development. Endocrinology 2012;153:6033-6040 , DOI 10.1210/en.2012-1324

3 Fukami FM, Wada FY, Okada FM, et al. Mastermind-like domaincontaining 1 (MAMLD1 or CXorf6) transactivates the Hes3 promoter, augments testosterone production, and contains the SF1 target sequence. J Biol Chem 2007;283:5525-5532, PMID:18162467

4 Zhuang FL, Bai FM, Zhou FW, et al. MAMLD1 gene mutation in the incidence of hypospadias in the Chinese population. J Med Biochem 2014;33;. Doi: 10.2478/jomb-2014-0018

5 Kalfa FN, Fukami FM, Philibert FP, et al. Screening of MAMLD1 mutations in 70 children with 46,XY DSD: identification and functional analysis of two new mutations. PLoS ONE 2012;7: e32505, DOI 10.1371/journal.pone.0032505

6 Nakamura FM, Fukami FM, Sugawa FF, Miyado FM, Nonomura FK, Ogata FT. Mamld1 knockdown reduces testosterone production and Cyp17a1 expression in mouse Leydig tumor cells. PLoS ONE 2011;6:e19123, DOI 10.1371/journal.pone.0019123

7 Kalfa FN, Cassorla FF, Audran FF, et al. Polymorphisms of MAMLD1 gene in hypospadias. J Pediatr Urol. 2011;7:585-591, DOI 10.1016/j. jpurol.2011.09.005

8 MacArthur FD, Altshuler FD, Ardissino FD, et al. ExAC Browser [online]. 2016. Exac.broadinstitute.org. Available at: http://exac. broadinstitute.org

9 van der Zanden FL, van Rooij FI, Feitz FW, Franke FB, Knoers FN, Roeleveld FN. Aetiology of hypospadias: a systematic review of genes and environment. Hum Reprod Update 2012;18:260-283, DOI 10.1093/humupd/dms002

10 Chen FY, Thai FH, Lundin FJ, et al. Mutational study of the MAMLD1gene in hypospadias. Eur J Med Genet 2010;53:122-126, DOI 10.1016/j.ejmg.2010.03.005

11 Kalfa FN, Liu FB, Ophir FK, et al. Mutations of CXorf6 are associated with a range of severities of hypospadias. Eur J Endocrinol 2008; 159:453-458, DOI 10.1530/EJE-08-0085

12 Kalfa FN, Sultan FC, Baskin FL. Hypospadias: etiology and current research. Urol Clin N Am 2010;37:159-166, DOI 10.1016/j. ucl.2010.03.010 